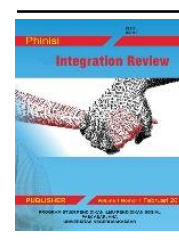

Phinisi Integration Review

Vol. 2, No.2, Agustus 2019 Hal 281-289

Website: http://ojs.unm.ac.id/pir

p-ISSN: 2614-2325 dan e-ISSN: 2614-2317

DOI: https://doi.org/10.26858/pir.v2i2.10006

\title{
Kesadaran Hukum Peserta Didik Dalam Berlalu Lintas
}

\author{
Mariani \\ Universitas Negeri Makassar \\ Email : marianipjk@gmail.com
}

\begin{abstract}
Abstrak. Tujuan penelitian ini adalah untuk mengetahui tentang (1) Tingkat kesadaran hukum berlalu lintas peserta didik di Kota Makassar; (2) Faktor yang mempengaruhi kepatuhan hukum berlalu lintas peserta didik di Kota Makassar; (3) Strategi yang dilakukan petugas (Polisi lalu lintas) untuk meningkatkan kesadaran hukum pada peserta didik. Penelitian ini adalah penelitian menggunakan kualitatif deskriptif. Metode pengumpulan data melalui observasi, wawancara dan dokumentasi serta analisis data yang dilakukan melalui reduksi data, display data dan verifikasi data. Hasil penelitian menunjukkan (1) Tingkat kesadaran hukum berlalu lintas peserta didik di Kota Makassar tergolong rendah, ini terlihat dari banyaknya jenis pelanggaran oleh peserta didik seperti tidak memiliki SIM, berkendara dengan kecepatan tinggi, tidak menggunakan helm, melawan arus dan menerobos lampu merah (2) Faktor yang mempengaruhi kepatuhan hukum berlalu lintas peserta didik di Kota Makassar adalah karena semata-mata takut akan sanksi. Ini sesuai dengan teori kepatuhan hukum yaitu Compliance (3) Strategi yang telah dilakukan oleh petugas (Polisi Lalu Lintas) untuk meningkatkan kesadaran hukum peserta didik dalam berlalu lintas di Kota Makassar adalah dengan cara meningkatkan pengetahuan dan kesadaran hukum peserta didik dalam berlalu lintas melalui upaya Preemtif, preventif dan represif secara maksimal.
\end{abstract}

Kata Kunci : kesadaran hukum, peserta didik, lalu lintas

\begin{abstract}
The study aims at examining (1) the traffic legal awareness of students in Makassar city, (2) the factors which influence traffic legal compliance of students in Makassar city, and (3) the strategies counducted by the police officers to improve legal awareness of students. The study was descriptive qualitative. Data were collected through observation, interview, and documentation. Data were analyzed by conducting data reduction, data display, and data verification. The results of the study reveal that (1) the traffic students in Makassar city was categorized as low, shown by numerous types of violatioans by students such as not having a driving license, driving at high speed, not using a helmet, going againts the flow, and breaking a red light. It was all due to low knowledge and understanding of the student on the regulation on road traffic, (2) the factors wich influence traffic legal compliance of students in Makassar city was afraid of sactions. It was in line with compliance theory, (3) the strategies which had been conducted by the police officers to improve legal awareness of students were by increasing students' knowledge and legal awareness in traffic through preemptive, preventive and repressive efforts.
\end{abstract}

Keywords: Legal awareness, students, traffic 
Phinisi Integration Review. Vol 2(2) Agustus 2019

(c) (1) () Ini adalah artikel dengan akses terbuka dibawah licenci CC BY-NC-4.0

https://creativecommons.org/licenses/by-nc/4.0/ ).

\section{PENDAHULUAN}

Negara Indonesia adalah Negara Hukum, ini sangat jelas sekali tertuang dalam Undang-Undang Dasar Negara Republik Indonesia Tahun 1945 Pasal 1 ayat (3) yang menyatakan bahwa "Negara Indonesia adalah negara hukum". Selanjutnya dalam Pasal 27 ayat (1) dikemukakan bahwa "segala warga negara bersamaan kedudukannya di dalam hukum dan pemerintahan dan wajib menjunjung hukum dan pemerintahan itu dengan tidak ada kecualinya".

Sebagai warga negara yang baik, sudah sepatutnya kita taat pada hukum positif (hukum yang sedang berlaku). Kesadaran hukum warga negara dapat terlihat dari perilaku dimana dia berada. Kesadaran hukum adalah kesadaran yang ada pada setiap manusia tentang apa hukum itu dan apa seharusnya hukum itu. Kesadaran hukum merupakan salah satu ciri bahwa masyarakat telah memahami dan mengerti hukum.

Dewasa ini permasalahan jumlah penduduk merupakan permasalahan yang memiliki dampak terhadap seluruh aspek kehidupan, salah satunya adalah permasalahan lalu lintas. Semakin banyaknya penduduk, semakin banyak pula pengguna sarana transportasi seperti mobil dan sepeda motor. Pertambahan volume kendaraan yang tidak disertai dengan penambahan ruas jalan atau volume jalan menyebabkan muncul permasalahan kemacetan lalu lintas yang dewasa ini hampir terjadi di berbagai daerah terutama di kota-kota besar seperti Kota Makassar. Kondisi semacam ini dapat mempengaruhi mobilitas masyarakat yang memiliki kepentingan dan keperluan yang beragam.

Lalu lintas yang aman, tertib, dan lancar merupakan dambaan seluruh lapisan masyarakat, khususnya para pengguna jalan raya. Hal tersebut akan menjamin terselenggaranya aktifitas berlalu lintas menuju terwujudnya kehidupan masyarakat yang tertib, aman, dan teratur. Sebaliknya, lalu lintas yang semrawut dan kacau balau akan membawa kesulitan, seperti menimbulkan kemacetan lalu lintas dan dapat menimbulkan kecelakaan.

Fenomena meningkatnya sepeda motor di Indonesia tentu saja ada sisi negatifnya, yaitu semakin tingginya angka kecelakaan lalu lintas yang terjadi di jalan raya. Kecelakaan bisa terjadi karena beberapa hal, seperti jalan yang rusak atau berlubang, pengendara yang sedang mengantuk, mengendarai sepeda motor dengan ugal-ugalan, tidak mematuhi peraturan lalu lintas dan tidak memiliki surat izin mengemudi.

Kesadaran hukum yang perlu di bangun adalah kesadaran hukum dalam berlalu lintas agar dapat meminimalisir pelanggaranpelanggaran hukum dalam berlalu lintas. Setiap pengendara seharusnya mengikuti aturan-aturan dalam berlalu lintas, dengan perilaku tertib agar dapat mencegah hal-hal yang dapat membahayakan keamanan dan keselamatan dalam berlalu lintas.

Kesadaran hukum peserta didik terhadap peraturan lalu lintas merupakan salah satu faktor penting dalam berlalu lintas. Kesadaran hukum perlu ditanamkan kepada seluruh peserta didik selaku pengguna jalan raya sebagai rasa tanggung jawab terhadap kenyamanan dalam berlalu lintas. Untuk mewujudkan peserta didik yang sadar hukum maka perlu adanya upaya agar peraturan tersebut dapat diketahui, dimengerti, dipatuhi, dan dihargai.

Rata-rata kecelakaan sepeda motor terjadi pada anak remaja. Orang tua cenderung memfasilitasi anaknya yang masih remaja untuk berangkat ke sekolah dengan menyetir sepeda motor sendiri, tanpa adanya pengawasan. Tentu saja untuk mengendarai kendaraan, baik itu roda empat atau roda dua tentulah harus memiliki surat ijin mengemudi yang dikeluarkan oleh pihak kepolisian.

Masalah pelanggaran Lalu Lintas saat ini berada dalam kondisi cukup mencemaskan 
bagi masyarakat di Kota Makassar. Hal ini dapat dilihat dari banyaknya pelanggaran lalu lintas oleh masyarakat secara umum dan peserta didik pada khususnya, sesuai dengan data yang diperoleh dari Satlantas Polrestabes Makassar.

Kesadaran hukum peserta didik pada kenyataannya masih berada dalam tingkat kesadaran hukum yang rendah, hal tersebut dapat terlihat dari banyaknya pelanggaran oleh peserta didik, khususnya di traffict light dan masih banyaknya peserta didik yang belum memiliki Surat Ijin Mengemudi (SIM) berkendara dijalan raya. Sebagian besar peserta didik belum memahami aturan tentang Lalu Lintas dan Angkutan Jalan yang sesuai dengan Undang-Undang No. 22 Tahun 2009. Sikap kurang patuh pada hukum dan tidak sadar akan pentingnya keteraturan dalam berlalu lintas masih kurang dipahami oleh kebanyakan peserta didik. Hal ini dapat dilihat dari penjelasan diatas mengenai pelanggaran lalu lintas di Kota Makassar pada tahun 2017 dilihat dari usia pelanggar yang termasuk usia pelajar yakni usia 0-15 tahun yang berjumlah 1.678 kasus dan pada usia 16-21 tahun yang jumlahnya 3.728 kasus. Rata-rata pelanggarannya adalah membawa kendaraan belum cukup umur sehingga tidak mampu memperlihatkan Surat Ijin Mengemudi (SIM) dan Surat Tanda Nomor Kendaraan (STNK), tidak mengenakan helm, dan melawan arus.

Tujuan Penelitian adalah (1) Untuk mengetahui tingkat kesadaran hukum peserta didik terhadap peraturan lalu lintas. (2) Untuk mengetahui faktor-faktor apa saja yang mempengaruhi kepatuhan hukum peserta didik dalam berlalu lintas. (3) Untuk mengetahui strategi yang telah dilakukan petugas (Polisi Lalu Lintas) untuk meningkatkan kesadaran hukum berlalu lintas

\section{TINJAUAN PUSTAKA}

\section{A. Konsep Kesadaran Hukum}

\section{Pengertian Kesadaran Hukum}

Simposium kesadaran hukum dalam masyarakat transisi mengemukakan bahwa kesadaran hukum itu meliputi pengetahuan tentang hukum, penghayatan tentang hukum dan ketaatan pada hukum. (Heri Tahir, 2010 : 114). Sementara itu, Setsuo Miyajawa menyatakan bahwa kesadaran hukum mempunyai tiga elemen, yaitu : persepsi (perception), pertimbangan nilai (value judgement), emosi (emotion) yang mengacu kepada tiga elemen sikap yang diberikan oleh Rosenberg dan Hovland. Analisis kesadarana hukum yang diharapkan untuk mengadakan penjelasan tingkah laku hukum individu pada tingkat terdekat yaitu tingkat motivasional. (Heri Tahir, $2010: 116)$

Kesadaran hukum merupakan suatu proses psikis yang yang terdapat dalam diri manusia, yang mungkin timbul dan mungkin juga tidak timbul. Jadi kesadaran hukum merupakan kesadaran atau nilai-nilai yang terdapat di dalam diri manusia tentang hukum yang ada atau tentang hukum yang diharapkan ada. Dengan demikian, jelaslah bahwa kesadaran hukum sebetulnya menjadi dasar bagi penegakan hukum sebagai proses. (Ishak, 2016 : 304)

Pada umumnya orang berpendapat bahwa kesadaran warga masyarakat terhadap hukum yang tinggi mengakibatkan para warga masyarakat mematuhi ketentuan peraturan perundang-undangan yang berlaku. Sebaliknya, apabila kesadaran warga masyarakat terhadap hukum rendah, derajat kepatuhannya juga rendah. Dengan demikian, masalah kesadaran hukum warga masyarakat sebenarnya menyangkut faktor-faktor apakan suatu ketentuan hukum tertentu diketahui, dipahami, ditaati dan dihargai. Apabila warga masyarakat hanya mengetahui adanya suatu ketentuan hukum, maka taraf kesadaran hukumnya lebih rendah dari mereka yang memahaminya, dan seterusnya. Hal itulah yang disebut legal consciousness atau knowledge and opinion about law. (Zainuddin Ali, 2005 : 66)

\section{B. Faktor yang Mempengaruhi Keefektifan Hukum}

1. Efektivitas hukum dalam masyarakat Bila membicarakan efektivitas hukum dalam masyarakat berarti membicarakan daya kerja hukum itu dalam mengatur dan/atau memaksa masyarakat untuk taat terhadap hukum. Efektivitas hukum dimaksud, berarti mengkaji kaidah hukum yang harus memenuhi syarat, yaitu berlaku secara yuridis, berlaku secara sosiologis, dan berlaku secara filosofis. Oleh karena itu, faktor-faktor yang dapat 
mempengaruhi hukum itu berfungsi dalam masyarakat, yaitu (1) kaidah hukum/peraturan itu sendiri; (2) petugas/penegak hukum; (3) sarana atau fasilitas yang digunakan oleh penegak hukum; (4) kesadaran masyarakat (Zainuddin Ali, 2005 : 62)

2. Arti penegakan hukum

Dalam hukum pidana, penegakan hukum adalah suatu sistem pengendalian kejahatan yang dilakukan oleh lembaga kepolisian, kejaksaan, pengadilan dan lembaga pemasyarakatan. (Kadri husin, 1999 : 2)

Penegakah hukum adalah kegiatan menyerasikan hubungan nilai-nilai yang terjabarkan di dalam kaidah-kaidah yang mantap dan mengejawantah dan sikap tindak sebagai rangkaian penjabaran nilai tahap akhir, untuk menciptakan, memelihara, dan mempertahankan perdamaian pergaulan hidup. (Soerjono Soekanto, 1993: 3)

3. Faktor yang mempengaruhi Penegakan hukum

soerjono Soekanto menulis bahwa penegakan hukum sebenarnya terletak pada faktor-faktor yang mungkin mempengaruhinya. Faktor-faktor tersebut mempunyai arti yang netral, sehingga dampak positif dan negatifnya terletak pada isi faktor tersebut. Faktor-faktor tersebut adalah sebagai berikut. (Heri Tahir, $2010: 115)$

a. Faktor hukumnya sendiri;

b. Faktor penegak hukum, yakni pihak-pihak yang membentuk maupun menerapkan hukum;

c. Faktor sarana atau fasilitas yang mendukung penegakan hukum;

d. Faktor masyarakat, yakni lingkungan di mana hukum tersebut berlaku atau diterapkan; dan

e. Faktor kebudayaan, yakni hasil karya, cipta, dan rasa yang didasarkan pada karsa manusia di dalam pergaulan hidup.

4. Pelaksanaan hukum

Pelaksanaan hukum selalu melibatkan manusia dan tingkah lakunya. Hukum tidak bisa terlaksana dengan sendirinya, artinya hukum tidak mampu untuk mewujudkan sendiri janji serta kehendak yang tercantum dalam peraturan hukum itu. (Ishak, $2016: 305$ )

\section{Faktor-faktor yang Mempengaruhi Kesadaran Hukum \\ Berikut merupakan faktor-faktor yang} mempengaruhi kesadaran hukum:

1. Pengetahuan Tentang Kesadaran Hukum

2. Pengakuan Terhadap Ketentuan Hukum

3. Penghargaan Terhadap Ketentuan Hukum

4. Penataan Terhadap Ketentuan Hukum

5. Ketaatan Masyarakat Terhadap Hukum

D. Faktor-Faktor yang Menyebabkan Masyarakat Mematuhi Hukum

Masalah kepatuhan hukum merupakan proses psikologis yang dapat ditinjau dari 3 (tiga) proses dasar. Adapun faktor-faktor yang dapat menyebabkan masyarakat mematuhi hukum antara lain sebagai berikut. (Soerjono Soekanto, 1982 : 230)

\section{Compliance}

Compliance diartikan sebagai suatu kepatuhan yang didasarkan pada harapan akan suatu imbalan dan usaha untuk menghindarkan diri dari hukuman yang mungkin dijatuhkan. Kepatuhan ini sama sekali tidak didasarkan pada suatu keyakinan pada tujuan kaidah hukum yang bersangkutan, dan lebih didasarkan pada pengendalian dari pemegang kekuasaan. Sebagai akibatnya, kepatuhan hukum akan ada apabila ada pengawasan yang ketat terhadap pelaksanaan kaidah-kaidah hukum tersebut.

\section{Identification}

Identification terjadi bila kepatuhan terhadap kaidah hukum ada bukan karena nilai intrinsiknya, akan tetapi agar keanggaotaan kelompok tetap terjaga serta ada hubungan baik dengan mereka yang diberi wewenang untuk menerapkan kaidah-kaidah hukum tersebut. Daya tarik untuk patuh adalah keuntungan yang diperoleh dari hubungan-hubungan tersebut, sehingga kepatuhanpun tergantung pada baik buruknya interaksi tadi.

\section{Internalization}

Seseorang mematuhi kaidah-kaidah hukum dikarekan secara intrinsik kepatuhan tadi mempunyai imbalan. Pusat kekuatan proses ini adalah kepercayaan orang tadi terhadap tujuan dari kaedah-kaedah bersangkutan, terlepas dari perasaan atau nilai-nilainya terhadap kelompok atau pemegang kekuasaan maupun pengawasannya. 


\section{E. Pengaturan UU Lalu Lintas di Dalam Hukum Positif Indonesia}

1. Undang-Undang Nomor 22 Tahun 2009

Undang-Undang Nomor 22 Tahun 2009

tentang Lalu Lintas dan Angkutan Jalan telah ditetapkan dalam Rapat Paripurna DPR RI pada tanggal 26 Mei 2009 yang kemudian disahkan oleh Presiden RI pada tanggal 22 Juni 2009. Undang-Undang ini adalah kelanjutan dari Undang-Undang Nomor 14 Tahun 1992, terlihat bahwa kelanjutannya adalah merupakan pengembangan yang signifikan dilihat dari jumlah clausul yang diaturnya, yakni yang tadinya 16 bab dan 74 pasal, menjadi 22 bab dan 326 pasal.

Lalu lintas berdasarkan Undang-undang No. 22 tahun 2009 didefinisikan sebagai gerak kendaraan dan/atau orang di ruang lalu lintas jalan adalah prasarana yang diperuntukkan bagi gerak pindah kendaraan, orang, dan/atau barang yang berupa jalan dan fasilitas pendukung. Pemerintah mempunyai tujuan untuk mewujudkan lalu lintas dan angkutan jalan yang selamat, aman, cepat, lancar, tertib dan teratur melalui manajemen lalu lintas dan rekayasa lalu lintas. Tata cara berlalu lintas di jalan di atur dengan peraturan perundangan menyangkut arah lalu lintas, prioritas menggunakan jalan, laju lalu lintas, jalur lalu lintas dan pengendalian arus di persimpangan. Lalu lintas diartikan sebagai gerak (bola balik) manusia atau barang dari satu tempat ke tempat lainnya dengan menggunakan sarana jalanan umum.

\section{METODE PENELITIAN}

Jenis penelitian ini adalah kualitatif, yaitu penelitian yang dilakukan untuk memahami fenomena tentang apa yang dialami oleh subyek penelitian misalnya, perilaku, persepsi, motivasi, tindakan dan lain-lain secara holistik dan dengan cara deskripsi dalam bentuk kata-kata dan bahasa, pada suatu konteks khusus yang alamiah dan dengan memanfaatkan berbagai metode alamiah.

Lokasi penelitian ini dilakukan di SMA Negeri 3 Makassar, SMK Telkom Makassar dan SMK Negeri 4 Makassar. Dalam penelitian ini pemilihan lokasi dilakukan secara purposive (sengaja) yaitu ditetapkan secara sengaja oleh peneliti berdasarkan atas kriteria atau pertimbangan tertentu dalam penelitian ini dengan maksud agar dapat mendeskripsikan dan menginterpretasikan data dalam keadaan atau peristiwa sebagaimana adanya, sehingga bersifat mengungkap fakta.

Dalam penelitian ini tekhnik yang dipakai dalam pengumpulan data adalah tekhnik observasi, wawancara dan dokumentasi. Ketiga tekhnik tersebut dijelaskan sebagai berikut:

1. Observasi

Observasi atau pengamatan adalah proses pengambilan data yang dilakukan penulis. Dalam penelitian ini dilakukan pengamatan secara langsung terhadap perilaku peserta didik dalam berlalu lintas jalan yang merupakan indikator tingkat kesadaran peserta didik. Pengamatan ini dilakukan di masingmasing sekolah yakni SMA Negeri 3 Makassar, SMK Negeri 4 Makassar dan SMK Telkom Makassar yang telah ditetapkan sebagai objek penelitian.

2. Interview (Wawancara)

Interview (Wawancara) yaitu kegiatan yang dilakukan untuk memperoleh data atau informasi dengan cara bertanya langsung kepada informan, yakni peserta didik dan polisi lalu lintas (polantas) tentang kesadaran hukum berlalu lintas pada peserta didik.

Wawancara merupakan salah satu cara untuk mengumpulkan data dengan jalan mengajukan pertanyaan-pertanyaan secara lisan kepada subjek penelitian, instrumen ini digunakan untuk mendapatkan informasi mengenai fakta, keyakinan, perasaan, niat dan sebagainya. Wawancara memiliki sifat yang luwes, pertanyaan yang diberikan dapat disesuaikan dengan subjek sehingga segala sesuatu yang ingin diungkap dapat digali dengan baik.

3. Dokumentasi

Dokumentasi yaitu pengambilan data yang diperoleh melalui dokumen-dokumen. Peneliti mengambil data maupun gambar yang relevan dengan penelitian yang berhubungan dengan aktivitas peserta didik dalam berlalu lintas jalan, data tersebut berupa catatatan pelanggaran ataupun kecelakan lalu lintas yang tercatat di kepolisian Polrestabes Makassar serta pengambilan gambar pada saat melakukan 
wawancara kepada peserta didik dan polisi lalu lintas (Polantas).

\section{HASIL DAN PEMBAHASAN}

\section{Tingkat Kesadaran Hukum Berlalu Lintas Peserta Didik di Kota Makassar}

a. Pengetahuan terhadap peraturan lalu lintas

Berdasarkan hasil wawancara yang dilakukan peneliti kepada pihak kepolisian yang memiliki program police goes to school yang intens melakukan sosialisasi ke sekolah-sekolah yang ada di Kota Makassar ternyata berbanding terbalik dengan keterangan peserta didik, sehingga mayoritas pengetahuan peserta didik terhadap Undang-Undang Nomor 22 Tahun 2009 tentang lalu lintas dan angkutan jalan masih tergolong rendah, karena dari wawancara yang peneliti lakukan terhadap peserta didik di tiga sekolah di kota Makassar hanya beberapa informan saja yang pernah mengikuti sosialisasi tertib dalam berlalu lintas.

Dari hasil wawancara terhadap beberapa peserta didik di tiga sekolah di Kota Makassar disimpulkan bahwa rata-rata peserta didik di SMA Negeri 3 Makassar dan SMK Negeri 4 Makassar belum pernah mengikuti sosialisasi tertib dalam berlalu lintas, hal ini dikarenakan peserta didik tidak mendapatkan informasi mengenai kegiatan tersebut dan kegiatan sosialisasi tersebut juga terkadang bertabrakan dengan jam pelajaran. Sedangkan peserta didik di SMK Telkom Makassar banyak yang pernah mengikuti sosialisasi tertib dalam berlalu lintas, meskipun demikian tampaknya tidak memberikan efek positif terhadap tingkat kepatuhan maupun kesadaran peserta didik terhadap aturan lalu lintas.

b. Pemahaman peserta didik terhadap peraturan lalu lintas

Berdasarkan wawancara yang telah peneliti lakukan terhadap beberapa peserta didik di SMA Negeri 3 Makassar, SMK Negeri 4 Makassar dan SMK Telkom Makassar, pemahaman informan terhadap peraturan dalam berlalu lintas tergolong baik. Hal ini dilihat dari beberapa jenis pertanyaan tentang tata cara berlalu lintas dan syarat-syarat untuk dapat mengendarai sepeda motor bisa dijawab dengan baik, begitu pula dengan jenis-jenis pertanyaan mengenai rambu-rambu lalu lintas yang diajukan pada informan dan hampir semua bisa dijawab dengan benar.

c. Tingkat Kesadaran dan kepatuhan peserta didik terhadap peraturan dalam berlalu lintas jalan

Dari hasil wawancara yang dilakukan peneliti, jelas terlihat masih banyak informan yang tidak sadar akan keselamatannya. informan pernah berkendara dengan kecepatan tinggi dikarenakan sedang terburu-buru untuk sampai ketempat tujuan. Tidak menggunakan helm apabila hanya berkendara didalam kompleks dan ditempat dekat. Bahkan ada informan yang mengatakan tidak menggunakan helm ketika berkendara, helm disimpan di bagasi motor dan kalau dilihat ada polisi baru memakainya. Melawan arus dikarenakan tempat yang dituju sangat dekat dan menerobos lampu merah dikarenakan sedang terburu-buru dan tidak ada polisi yang berjaga-jaga. Disini terlihat bahwa kesadaran hukum peserta didik dalam berlalu lintas masih sangat rendah meskipun pemahamannya sudah baik.

\section{Faktor yang Mempengaruhi Tingkat Kepatuhan Hukum Berlalu Lintas Peserta Didik di Kota Makassar}

a. Pengetahuan hukum berlalu lintas jalan

Dari hasil penelitian yang dilakukan melalui wawancara, informan hanya menjawab seadanya dan hanya berdasarkan pengalamannya dalam keseharian berlalu lintas jalan bukan berdasarkan apa yang memang diketahuinya dari aturan-aturan yang berlaku dalam hal ini yaitu UU RI Nomor 22 Tahun 2009 tentang Lalu Lintas dan Angkutan Jalan. Beberapa jawaban dari informan terkadang melenceng ataupun tidak lengkap dari apa yang sudah tertuang dari aturan yang berlaku.

a. Kesadaran dan kepatuhan dalam berlalu lintas jalan

Berdasarkan hasil penelitian yang dilaksanakan melalui wawancara, dapat dipastikan tingkat pemahaman peserta didik terhadap kegunaan alat transportasi dan dalam mematuhi peraturan berlalu lintas jalan sangatlah tinggi. informan berpendapat sangatlah penting, namun hal tersebut tidak sejalan dengan perilaku informan dalam 
mematuhi aturan tersebut, ini terlihat dari keterangan informan berdasar hasil wawancara, mayoritas peserta didik belum memiliki SIM dengan alasan belum bersyarat untuk memiliki SIM karena dianggap belum cukup umur untuk berkendara. peserta didik pernah melakukan pelanggaran terhadap peraturan lalu lintas seperti berkendara dengan kecepatan tinggi, tidak menggunakan helm, melawan arus dan menerobos lampu merah. Pelanggaran tersebut dilakukan karena sedang terburu-buru, jalanan lagi sepi dan tidak ada polisi yang berjaga-jaga.

Hasil penelitian mendukung teori yang sudah ada, bahwa faktor-faktor yang mempengaruhi kepatuhan hukum berlalu lintas peserta didik di Kota Makassar adalah karena semata-mata hanya takut akan sanksi. Ini sesuai dengan teori kepatuhan hukum yaitu Compliance.

\section{Strategi yang Dilakukan Petugas (Polisi Lalu Lintas) Untuk Meningkatkan Kesadaran Hukum Peserta Didik Dalam Berlalu Lintas di Kota Makassar}

Sebagaimana hasil penelitian melalui wawancara terhadap Petugas (Satlantas) Polrestabes Kota Makassar, bahwa dalam meningkatkan kesadaran dan kepatuhan hukum peserta didik, maka upaya-upaya yang dilakukan akan di maksimalkan, dalam hal ini salah satu upaya dan merupakan langkah awal yaitu melalui upaya preemtif. Upaya preemtif merupakan upaya yang dilakukan melalui sosialisasi/penyuluhan tentang berlalu lintas yang baik dan benar sesuai dengan UndangUndang Nomor 22 Tahun 2009 tentang Lalu Lintas dan Angkuta Jalan ke sekolah-sekolah yang ada di Kota Makassar yang materinya akan disesuaikan dengan tingkat pendidikan. Sekaitan dengan hal itu maka upaya ini perlu ditingkatkan baik dari segi kualitas maupun kuantitasnya khususnya buat peserta didik itu sendiri. Selanjutnya penertiban berlalu lintas jalan yang merupakan upaya preventif yang dilakukan berupa tindakan pencegahan sebelum terjadinya pelanggaran dan terlebih untuk menghindari terjadinya dampak dari pelanggaran itu sendiri dan terakhir adalah penegakan hukum yang merupakan upaya represif yang berupa tindakan setelah terjadinya pelanggaran yang bertujuan untuk memberikan efek jera terhadap pelanggar lalu lintas.

\section{SIMPULAN DAN SARAN}

Dari uraian hasil penelitian maka ditarik kesimpulan sebagai berikut:

1. Tingkat kesadaran hukum berlalu lintas peserta didik di Kota Makassar tergolong rendah, ini terlihat dari banyaknya jenis pelanggaran oleh peserta didik seperti tidak memiliki SIM, berkendara dengan kecepatan tinggi, tidak menggunakan helm, melawan arus dan menerobos lampu merah.

2. Faktor yang mempengaruhi kepatuhan hukum berlalu lintas peserta didik di Kota Makassar adalah karena semata-mata takut akan sanksi. Ini sesuai dengan teori kepatuhan hukum yaitu Compliance.

3. Strategi yang telah dilakukan oleh petugas (Polisi Lalu Lintas) untuk meningkatkan kesadaran hukum peserta didik dalam berlalu lintas di Kota Makassar adalah dengan cara meningkatkan pengetahuan dan kesadaran hukum peserta didik dalam berlalu lintas melalui upaya Preemtif, preventif dan represif secara maksimal.

Dari kesimpulan penelitian, maka diajukan saran sebagai berikut:

1. Diharapkan kepada seluruh peserta didik agar meningkatkan tingkat kesadaran hukum dalam berlalu lintas, karena hal ini tidak hanya berkaitan dengan pribadi peserta didik yang bersangkutan tetapi juga berkaitan dengan masyarakat secara luas.

2. Hendaknya peserta didik mematuhi aturan hukum bukan hanya sekedar untuk terhindar dari sanksi saja tetapi harus menanamkan didalam diri bahwa kepatuhan adalah hal yang bermanfaat untuk dirinya dan bukan hanya sebatas kewajiban melainkan suatu kebutuhan.

3. Demi tercapainya tujuan untuk meningkatkan kesadaran hukum peserta didik dalam berlalu lintas jalan diharapkan semua lapisan masyarakat dapat berperan serta secara aktif supaya tercipta ketertiban, kenyamanan dan keselamatan bersama. 
Phinisi Integration Review. Vol 2(2) Agustus 2019

\section{DAFTAR RUJUKAN}

Asikin, Zainal, 2013. Pengantar Ilmu Hukum, Jakarta : Rajawali Pers

AW. Widjaja, 1984. Kesadaran Hukum Manusia dan Masyarakat Pancasila, Jakarta : CV. Era Swasta

Bisri, I, 2005. Pelajaran Hukum Pidana. Jakarta : PT Raja Grafindo Persada

Bungin, Burhan, 2009. Penelitian Kualitatif : Komunikasi, Ekonomi, Kebijakan Publik, dan Ilmu Sosial, Jakarta : Kencana Pernada Media Group

Chazawi, A, 2005. Pelajaran Hukum Pidana. Jakarta : PT Raja Grafindo Persada

C.S.T. Kansil, 2002. Pengantar Ilmu Hukum dan Tata Hukum Indonesia Jilid I, Jakarta : Balai Pustaka

Djajoesman,H.S. 1986. Polisi Dan lalu Lintas. Bandung : Bina Aksara

Heri Tahir, 2010. Proses Hukum Yang Adil dalam Sistem Peradilan Pidana Di Indonesia. Yogyakarta : LaksBang PRESSindo

Ishaq, 2016. Dasar-Dasar Ilmu Hukum. Jakarta : Sinar Grafika

Kadri Husin. 1999. Diskresi dalam Penegakan Hukum Pidana di Indonesia (Suatu Analisis Penegakan HAM dalam Peradilan Pidana). Pidato Pengukuhan Guru Besar Tetap Ilmu Hukum Pidan Fakultas Hukum Universitas Lampung. Bandar Lampung : Universitas Lampung.

Moleong, J.Lexy. 2007. Metodologi Penelitian Kualitatif. Bandung: Rosdakarya.

Muhammad Erwin, 2011. Filsafat Hukum. Jakarta : PT RajaGrafindo Persada
Paizaluddin, Ermalinda. 2013. Penelitian Tindakan Kelas Panduan Teoritis danPraktis. Bandung: Alfabeta.

Rahardjo, Sadjipto, 2002. Sosiologi Hukum Perkembangan Metode dan Pilihan Masalah. Yogyakarta : UMS Press

Rianto Yatim.1996. Metodologi Penelitian Pendidikan. Jakarta: SIC.

R. Soeroso, 2017 Pengantar Ilmu Hukum. Jakarta : Sinar Grafika

Sanusi, A. 1991. Pengantar Ilmu Hukum dan Pengantar Tata Hukum Indonesia. Bandung : Tarsito

Satjipto Raharjo. tt. Hukum dan Masyarakat. Bandung: Angkasa

Soerjono Soekanto. 1982. Kesadaran Hukum \& Kepatuhan Hukum. Jakarta : CV Rajawali.

1983. Teori Sosiologi Tentang Perubahan Sosial. Jakarta : Ghalia Indonesia

1990. Polisi dan Lalu Lintas (Analisis Menurut Sosiologi Hukum) . Bandung : Bandar maju.

1993. Faktor-Faktor yang Mempengaruhi Penegakan Hukum. Jakarta : Raja Grafindo Persada.

Sugiyono. 2012. Metode Penelitian Kombinasi (Mixed Methods). Bandung: Alfabeta.

Sugiarto, U. S. 2013. Pengantar Hukum Indonesia. Jakarta Timur : Sinar Grafika

Zainuddin Ali, 2006. Sosiologi Hukum. Jakarta : Sinar Grafika

https://www.merdeka.com/peristiwa/operasizebra-2017-di-sulsel-pelajar-pelanggar terbanyak-kedua.html, diakses 4 Juli 2018.

http://usmanunram.blogspot.com/2015/01/kesad aran-hukum.html, diakses 4 Juli 2018 
https://materiips.com/faktor-yangmempengaruhi-kesadaran-hukum, diakses 7 Juli 2018

Undang-undang Dasar Negara Republik Indonesia Tahun 1945. Jakarta : Majelis Permusyawaratan Rakyat

Undang-Undang Republik Indonesia No. 22 Tahun 2009 tentang Lalu Lintas dan Angkuta Jalan dan Peraturan Pemerintah Republik Indonesia Nomor 55 Tahun 2012 tentang kendaraan, 2013. Surabaya : Kesindo Utama 